\title{
A INTERDISCIPLINARIEDADE ENTRE ARQUIVOLOGIA E LINGUAGEM: A CIÊNCIA À LUZ DA PERSPECTIVA DIALÓGICA DO DISCURSO
}

\author{
Eliete Correia dos Santos \\ Doutora em Linguística \\ Professora do Curso de Arquivologia da UEPB \\ professoraeliete@hotmail.com \\ Vancarde Brito Sousa \\ Doutor em Sociologia \\ Professor do Curso de Arquivologia da UEPB \\ vancarder@hotmail.com \\ Jacqueline Echeverría Barrancos \\ Doutora em Administração \\ Professora do Curso de Arquivologia da UEPB \\ unijacqueline@gmail.com
}

Resumo

\begin{abstract}
A Arquivologia, como ciência, é um fenômeno contemporâneo e se configura com perspectivas além da imediaticidade da gestão arquivística, como uma ciência em permanente construção, dotada de autonomia e interdisciplinarmente construída nas relações com outras ciências. Assim, objetivo desse artigo é refletir a concepção de ciência à luz dos estudos bakhtinianos para a Arquivologia, assumindo uma postura de cooperação entre as áreas interdisciplinares. As bases do pensamento do Círculo de Bakhtin são construídas a partir da crítica às duas tendências filosóficas: a estilística clássica que se baseia no idealismo e o estruturalismo situado nos estudos do sistema abstrato. $\mathrm{O}$ objeto é ser expressivo e falante, e a concepção de linguagem é entendida como processo de interação social fundamentada no diálogo com o outro (relaciona-se à ideia de sujeito social, histórica e ideologicamente situado, que se constitui na interação com o outro) e na unidade das diferenças.
\end{abstract}

Palavras-chave: Ciência. Linguagem. Arquivologia. Interdisciplinaridade. Diálogo.

\section{INTRODUÇÃO}

A relativização do domínio quase absoluto das instituições arquivísticas quanto à produção e à legitimação do conhecimento por décadas vem diminuindo e se abrem novos espaços nas universidades para discussão epistemológica do próprio campo empírico, de seus objetos, de seus métodos. A Arquivologia, como ciência, é um fenômeno contemporâneo e se configura com perspectivas além da imediaticidade da gestão arquivística o que leva a um estudo distintivo entre pesquisas em arquivos realizadas por cientistas sociais e pesquisas em Arquivologia sobre as diversas dimensões arquivísticas.

As visões são distintas e trazem contribuições e/ou distorções ao construir a pesquisa na área ${ }^{1}$. Há trabalhos que seguem a linha da Arquivologia como um campo autônomo e uma ciência auxiliar da História, ou a Arquivologia como uma disciplina que constitui uma subárea da Ciência da Informação, e a vertente que investiga a Arquivologia como uma ciência em permanente construção, dotada de autonomia e interdisciplinarmente construída nas relações com outras ciências, tais como a Linguística, Administração, Ciência da Informação, História, entre outras (JARDIM, 2012).

Apostando nessa última vertente, o grupo de pesquisa em Arquivologia e Sociedade GPAS da UEPB assume uma postura interdisciplinar de investigar a área. A interdisciplinaridade tem sido definida como uma estratégia que busca a união de diferentes 
disciplinas para tratar um problema comum. Nesse caso, pode-se entender como um procedimento metodológico relacionado com o processo de "finalização das ciências", que, como resultado de ter alcançado um estado de "maturidade", deveria levá-las a redirecionar seu potencial aplicativo para a demanda social de conhecimentos, internalizando uma exigência de "reintegração" e "retotalização".

É nesse sentido que diversas ciências podem repartir tarefas de pesquisa, sem se afastar de seus conceitos e métodos, para contribuir em um projeto ou em uma problemática comum. Esses processos, que correspondem ao que se denomina uma interdisciplinaridade técnica, integram uma série de ciências e tecnologias aplicadas como uma divisão do trabalho intelectual, científico e técnico, tanto nos processos de produção, como em um conjunto de projetos sociais.

A interdisciplinaridade é, ao mesmo tempo, requisito e sinal de um mundo diferente: novos procedimentos científicos e técnicos e novo estilo de civilização. Tem como função desenvolver no sujeito um processo de pensamento que o torne capaz de enfrentar novos objetos de conhecimento, buscar uma nova síntese.

O ponto principal da concepção de interdisciplinaridade desse grupo de pesquisa é definida, a partir de Bakhtin (2010a), de Zonas Fronteiriças. Acredita-se que as demarcações de cada disciplina contribuem para entender o objeto multifacetado, com vários pontos de vista. É justamente nas zonas fronteiriças de cada disciplina em relação à outra que a dimensão da cooperação atua, respeitando o conhecimento epistemológico e metodológico utilizado em cada uma delas. Nas zonas fronteiriças de integração, há abertura para o diálogo sem que isso implique abandono da identidade disciplinar originária. (SANTOS, 2013).

Assim, o objetivo desse artigo é refletir a concepção de ciência à luz dos estudos bakhtinianos para a Arquivologia, assumindo uma postura de cooperação entre as áreas interdisciplinares.

\section{MÉTODO OU DIRETRIZES PARA AS CIÊNCIAS HUMANAS E CIÊNCIAS SOCIAIS APLICADAS?}

O gênero discursivo vive do presente, mas sempre recorda o seu passado, o seu começo (BAKHTIN/VOLOCHÍNOV, 1981). É o representante da memória criativa no processo de desenvolvimento literário. Dessa forma, nesta seção, refletimos sobre as Ciências Humanas para que possamos discorrer sobre o objeto científico em Arquivologia. Embora Bakhtin (2010a) apresente apenas a metodologia para Ciências Humanas ${ }^{2}$, consideramos essa área também como Social, por reconhecer que é uma via de mão dupla, dialética entre o humano e o social, em que uma depende da outra para ser investigada, pois não há objeto científico que não seja mediatizado por texto; além disso, por entender que nosso objeto de estudo transita entre a Linguística, a Educação e a Arquivologia.

Bakhtin se via como um pensador e não como um cientista, preso à positividade e à modelização formal e se colocava fora de uma racionalidade propriamente científica, desenvolvia um pensamento mais livre transcendendo as fronteiras de disciplinas e metodologias estabelecidas. Para ele, o mundo não é um objeto calculável com um modelo instrumentalizante de uma análise científica. Até o fim de sua vida, deixou muito clara a sua recusa às correntes do pensamento do objetivismo abstrato e subjetivismo individualista e a abertura à discussão das ciências humanas como fundamentalmente hermenêuticas.

Faraco (2009) adverte sobre as diversas procuras dos textos de Bakhtin (e do Círculo) como um método científico, vários pesquisadores se aproximam deles na expectativa de encontrar um conjunto de procedimentos para a análise literária e para a análise linguística e aponta que, em busca de uma cientificidade, transformam categorias filosóficas em categorias científicas, em categorias de método, em especial a polifonia, o diálogo, a carnavalização. Mesmo os trabalhos de "Voloshinov e Medvedev, comprometidos com o pressuposto de cientificidade do pensamento marxista, dificilmente podem ser lidos como contendo recortes de 'objetos calculáveis' e formalizações de proposições de método." (FARACO, 2009, p. 39). 
Os textos do Círculo de Bakhtin, em nenhum momento, apresentam uma formalização de método científico, mas sim diretrizes para conhecermos melhor o objeto estudado $^{1}$; e também o fazer científico nas ciências humanas materializado por gestos interpretativos, por contínua atribuição de sentidos. Em seu texto "Metodologia das ciências humanas", parece que o pensamento desse filósofo sobre ciências humanas foi inspirado na leitura dos textos do alemão Dilthey (1833-1911), que recusava a concepção positivista ao pretender reduzir as ciências humanas e sociais às ciências naturais, no entanto Bakhtin critica o psicologismo inerente ao raciocínio de Dilthey ao mostrar como ele constituíra um sistema em que o psiquismo tem primazia sobre o universo da cultura, desconsiderando a dimensão social.

Para Bakhtin (2010a), a consciência individual é construída pela interação verbal e o universo da cultura tem primazia sobre o psiquismo. O objeto das ciências humanas é o "ser expressivo e falante", ou seja, o objeto da pesquisa é objeto falado, é o próprio texto fazendo um duplo movimento: como resposta ao já dito e também sob o condicionamento da resposta ainda não dita, mas solicitada e prevista, assim o objeto também é falante a explicar e compreender.

Bakhtin diferencia o que ele vê entre as ciências com relação ao objeto. Nas ciências naturais, uma relação monológica porque o objeto é mudo; nas ciências humanas ${ }^{2}$ (ciências do espírito), uma relação dialógica porque o objeto é um texto. Nas ciências naturais, o sujeito contempla e fala sobre uma coisa muda; nas ciências humanas, há pelo menos dois sujeitos sociais e historicamente localizados, o que analisa e o analisado. Desse modo, no dizer desse filósofo, as ciências humanas se debruçam sobre a significação e trabalham com a compreensão e não apenas com a explicação. (ver BAKHTIN, 2010a; AMORIM, 2004, 2006; Faraco, 2009). "A compreensão como visão de sentido, não uma visão fenomênica e sim uma visão do sentido

\footnotetext{
${ }^{1}$ Ver a 3. ${ }^{a}$ parte do texto de Marxismo e Filosofia da Linguagem (1981).

${ }^{2}$ Amorim (2004) adverte que o fato de ter o homem como objeto não define as ciências humanas. Essa concepção perde a validade nas abordagens que supõem uma continuidade entre natureza e cultura.
}

vivo da vivência na expressão, uma visão do fenômeno internamente compreendido, por assim dizer, autocompreendido." (BAKHTIN, 2010a, p. 396).

Nesse conjunto de diferenciações entre ciências naturais e humanas, o que nos importa entender sobre o dizer de Bakhtin sobre ciências humanas é a capacidade de não fundir em um só os dois sujeitos (o pesquisador e o pesquisado), não refrear a alteridade daquilo que é outro sem transformar em qualquer coisa que é para si. "Compreender ${ }^{3}$ não deve excluir a possibilidade de uma modificação de seu próprio ponto de vista. $\mathrm{O}$ ato de compreensão supõe um combate onde o que está em jogo reside numa modificação e num enriquecimento recíprocos." (BAKHTIN, 2010 b, p. 249). Dessa maneira, não existe sentido anterior ou último; segundo esse filósofo, há progressão dialógica que parte do texto e daquilo que existe nos contextos passados a chegar à frente, o começo de um contexto futuro, assim um contexto inacabado sem limitação para o contexto dialógico de um texto. "Isto confere às ciências humanas um caráter provisório e plural que deverá se defrontar com o imperativo da explicação e da formulação de leis tendendo ao universal" (AMORIM, 2004, p. 193).

A respeito desse aspecto, Amorim (2004) discute com ênfase essa concepção bahktiniana das ciências humanas como espaço de tensão dialógica ao afirmar que um texto só pode se dizer através de um outro e a cada vez que é lido um novo sentido é declarado; a reinterpretação e a releitura são a marca dessas ciências, o destino de toda grande obra nesse campo e nisso consiste a maior parte da atividade do pesquisador em ciências humanas: reler e reescrever. Um olhar mais atento de um objeto em uma mesma cultura se perceberá que se relê textos teóricos ou se reinterpreta textos recolhidos em campo.

Se pensarmos a aprendizagem de uma linguagem de especialidade com relação ao uso informal de algumas expressões, por exemplo, o suposto erro poderia ter várias

O que não impede que o homem seja estudado por abordagens cognitivistas ou etológicas, visões opostas de Bakhtin em que o estudo do homem é não natural e o acesso da cultura é descontínuo.

${ }^{3}$ Bakhtin usa compreender e interpretar como equivalentes. 
significações, vários sentidos. Em uma pesquisa chomskiana, a competência das estruturas seria estudada e generalizada, em um contexto sociolinguístico, seria observado o uso de uma variação linguística e o preconceito estabelecido entre as esferas de uso, em uma interpretação sociológica, poderia ser interpretada como uma resistência cultural às normas cultas. Assim, se mudarmos o olhar teórico, poderíamos ter outras interpretações, como disse Saussure (1975), o ponto de vista é que define o objeto. É justamente isso que Bakhtin discute: a bipolaridade entre a explicação e a interpretação, entre o conceito e o sentido, o reprodutível e o irreprodutível, o lógico e o dialógico (cf. BAKHTIN/ VOLOCHÍNOV, 1981; AMORIM, 2004). ${ }^{4}$

Amorim (2004) acresce a ideia de proximidade de um polo ou de outro, a tentativa de supressão de um ou de outro, o desafio de encontrar um equilíbrio entre os dois, na vasta heterogeneidade de textos. Polos opostos que não se excluem e se devem confrontar no interior de um mesmo trabalho. Nesse jogo de tensões, sustentar a diferença, a exotopia e a bivocalidade em um movimento que deve inscrever o outro em nosso universo de questões, mas sem reduzi-lo para que se possa sempre ouvir a sua voz, o que a autora define como uma abordagem polifônica das ciências humanas. A alteridade do objeto torna-se interlocução e funda assim a especificidade do discurso das ciências humanas. Nesse sentido, a autora propõe uma dupla inversão.

Inversão dupla operada pelo texto de pesquisa em relação à situação enunciativa de campo: o outro ao qual o texto se dirige é um ele e o outro de que fala é um $t u$. Se a voz do objeto é real posto que fala no texto, a enunciação que dispõe o objeto como tu e o destinatário como ele só existe como funcionamento textual. É preciso não confundir a composição enunciativa do texto com a enunciação real que se deu na situação de campo. Na enunciação real, o outro era o $t u$ ao qual se dirigia o pesquisador e que tomava a palavra tornando-se um eu. No texto, o outro está necessariamente no lugar do

\footnotetext{
${ }^{4}$ Amorim (2004) apresenta essa questão a respeito desses pares de oposição e dos pares sobre teoria do signo contidos em Marxismo e Filosofia da Linguagem. A autora levanta uma possibilidade
}

objeto, logo do ele. Que sua voz faça no texto o papel de um $t u$ que interfere na palavra do autor obrigando-o a lhe responder, não restitui magicamente a copresença do outro. (AMORIM, 2004, p. 198-199).

Desse modo, o leitor estará no lugar do tu, tomará a palavra e dará um sentido a ela com suas próprias palavras que é exterior e posterior ao texto. A dupla inversão do texto de pesquisa em ciências humanas designa, pois, uma enunciação segunda e composicional. Do mesmo jeito, de acordo com a autora, o eu, ao aparecer no texto, é condição segunda, é reveladora a apresentação sob forma de um nós ou de se. Enquanto locutor (nós ou se), será marcado pela particularidade e parcialidade do ponto de vista e das questões que ele propõe. Embora a impressão seja de generalização para conceptualizar ou formular princípios de sistematização, é uma voz presente no texto. Falar como um eu no texto científico passa-se a ideia de uma cumplicidade muda e sem objeção ao vivido por alguém. Renunciar a pretensão de que o se produz um enunciado no qual ninguém fala é desprezar a concepção de inacabamento do texto.

Parece-nos ser esse um dos desafios para se construir ciência em Arquivologia, como ser aceito em um universo culturalmente formado de normas e princípios, mas com a clareza do meu posicionamento diante dos vários outros, das relações estabelecidas entre o objeto, entre o sujeito e o objeto, entre os sujeitos que participam antes, durante e após o meu texto. Resumidamente, Amorim (2004) apresenta duas proposições de esboço para uma abordagem polifônica das ciências humanas: A dupla inversão como dispositivo textual de base que dispõe os papéis enunciativos mínimos de um acontecimento cuja resultante é imprevisível; o carnaval como variantelimite da abordagem polifônica - sua impossibilidade no texto científico e sua função pré ou pós-teórica da desarrumação e renovação da pesquisa.

Assim, a análise é voltada para o objeto e não busca a subjetividade do pesquisador, e afirma dois princípios de trabalho (AMORIM,

que Bakhtin poderia ter formulado uma teoria dialética das ciências humanas e deixa a pergunta se não o fez por tempo ou por escolha. 
2004, p. 207): “1. A recusa de um subjetivismo relativista onde o objeto seria inteiramente reduzido ao modo como dele se fala; 2 . A recusa da ilusão positivista ou do pressuposto fenomenológico de que é possível falar das coisas 'tal como elas são"'.

$\mathrm{O}$ objeto das ciências humanas existe independente de mim, antes e depois de mim, ele é o próprio discurso, em suas variadas fases, seja de construção, de recolhimento ou de transmissão. A problematização dos contextos de interpretação, distantes ou não, fundamenta-se em uma renovação interminável dos sentidos em todos os contextos novos que podem ser investigados em dois tempos: "o pequeno tempo - a atualidade, o passado imediato e o futuro previsível - ou o grande tempo - o diálogo infinito e inacabável em que nenhum sentido morre" (BAKHTIN, 2010a, p. 409).

No dizer de Bakhtin, podemos pensar como responsabilidade do pesquisador a unidade entre teoria, ética e estética; um agir do sujeito consciente de sua responsabilidade de sujeito humano que responde à sociedade pelos seus atos, em uma "inter-relação entre o mítico (mythos) - que é coesivo, mas repetitivo -, o prático (métis) - que é vivo, mas contingente - e o teórico (logos), que é somativo, mas pode distanciar-se do aqui e agora" (SOBRAL, 2005, p. 118).

Sobral (2005, p. 118) adverte que o agir do sujeito, nos planos citados anteriormente, deve ter condições de impedir que:

a. O logos (a razão, o discurso) ceda ao mythos (a repetição, o abstrato) e desdenhe a métis (o prático, o concreto);

b. O mythos instaure o discurso único, indiscutível (anti-logos) e abstrato (antimétis);

c. A métis imponha a singuralidade como único critério de valor e sufoque tanto a necessária generalização que o logos propicia em sua dialogicidade como a coesão que $o$ mythos propicia, evitando a queda na luta de todos contra todos.

Enfim, fazer ciência em Arquivologia, em uma postura bakhtiniana, equivale a definir como percebemos essas relações entre os

\footnotetext{
${ }^{5}$ Neste texto, ao se referir a essa obra, não faremos alusão ao Círculo de Bakhtin, mas seguiremos a
}

aspectos generalizáveis e os aspectos particulares do objeto estudado, entre as expectativas do pesquisador e a realidade do objeto em um plano ético. A escrita, nesse sentido, não é mecânica, é construção permanente de discursos sociais e históricos do ser no mundo do sujeito pesquisador que apresenta uma avaliação responsável de suas ações nas coerções de suas relações sociais.

Acreditamos que as diretrizes traçadas pelo Círculo bakhtiniano nos apresentam o caminho de se pensar não apenas as categorias filosóficas - já discutidas por vários autores -, mas, sobretudo, categorias de um método para ciências humanas, que podem representar uma maneira de ser visto o discurso de outrem com mais ética ao ser citado no texto ou objeto de pesquisa do investigador, uma compreensão das fronteiras da interação verbal.

Entender as ciências humanas e sociais aplicadas à luz do pensamento do círculo bakhtiniano nos permite perceber que a consciência individual se amplia na interação com os outros, na interação com uma realidade idealizada, mediada pela cultura: a participação em atividades no mundo medeia o individual e o social. Assim, escrever e fazer ciência na academia só é importante na medida em que nos possibilita desempenhar determinados papéis em uma sociedade. Sob essa perspectiva, achar lugar para a escrita na vida do aluno não é suficiente, é preciso e requer muito mais, como veremos na próxima seção.

\section{O OBJETO DAS CIÊNCIAS HUMANAS E SOCIAIS APLICADAS}

O objeto das ciências humanas para o Círculo de Bakhtin é o ser expressivo e falante, por isso não se trata apenas de contribuição para a linguística ou literatura; refere-se a uma concepção do ser semiótico no mundo dos sujeitos de, uma concepção filosófica de como a cultura, juntamente aos sujeitos, institui e adquire sentido, em sua própria relação simbólica com o mundo dado e o transformam necessariamente em mundo postulado.

A concepção dialógica de Bakhtin/Volochínov (1981) ${ }^{5}$ amplia as

tradução brasileira na qual aparecem os nomes dos dois autores (Bakhtin e Volochínov). 
reflexões sobre a língua para além da estrutura, focalizando o discurso no seu contexto sóciohistórico. Esses autores constroem uma nova forma de pensar a linguagem a partir da crítica às duas tendências vigentes nos anos vinte do século passado: a estilística clássica que se baseia no idealismo e o estruturalismo situado nos estudos do sistema abstrato. Essas teorias não davam conta do funcionamento da língua e surge a terceira tendência que considera a linguagem em uso e o sujeito inserido na história produzindo sentido nessa interação.

Bakhtin/Volochínov (1981) consideram limitada a teoria da expressão do subjetivismo idealista, que tomou o objeto de estudo como enunciação monológica isolada e exclui qualquer réplica ativa ou resposta, e mostram que o processo de compreensão exige sempre uma resposta ativa. $\mathrm{O}$ problema do ato passivo nada tem a ver com a atividade de linguagem, pois exclui a possibilidade de abertura que esta permite e limita a pluralidade de leituras que esse modo de ver oferece. $O$ ato de compreender não se reduz à decodificação e alcança uma amplitude maior do que aquela que se fecha no interior da mente. Um ponto que podemos destacar da rejeição de Bahktin a essa tendência é que a expressão é tudo aquilo que, tendo se formado e determinado de alguma maneira no psiquismo do indivíduo, exterioriza-se objetivamente para outrem com a ajuda de algum código de signos exteriores, ou seja, a expressão comporta, portanto, duas facetas: o conteúdo (interior) e sua objetivação exterior para outrem (ou também para si mesmo).

A outra crítica incide sobre a orientação do pensamento filosófico do objetivismo abstrato fundamentado no sistema linguístico estável e constituído por formas independentes da situação social. A ênfase está na linguística estruturalista, que valoriza mais o objeto do que o sujeito; enfatiza mais a forma do que o conteúdo e considera o significado no nível da língua. Essa visão de língua considera que o sentido está no texto e os sujeitos interpretam de forma sempre idêntica as mensagens que trocam.

Para ilustrar essas posições, temos de retomar os estudos linguísticos do século XX, iniciados por Saussure no século XIX, por buscar um método ou um estatuto científico para os estudos da linguagem. Para Saussure (1975, p. 17), “a língua é ao mesmo tempo, um produto social da faculdade de linguagem e um conjunto de convenções necessárias, adotadas pelo corpo social para permitir o exercício dessa faculdade aos indivíduos." Já a linguagem, tomada em seus diferentes domínios, é ao mesmo tempo física, fisiológica e psíquica, pertencendo ao domínio individual e ao social. Desse modo, deriva-se uma divisão entre língua e fala em que esta é individual e, portanto, fica à margem dos estudos, junto a outros elementos constitutivos do ato comunicativo: o sujeito e os aspectos sóciohistóricos do discurso. Essa teoria constituiu um avanço significativo para a época.

A distinção entre língua e linguagem foi mais um alvo das críticas, na qual Saussure observa que aquela ocupa uma posição privilegiada e de autonomia em relação à linguagem. A língua é vista por sua parte formal ou por suas regularidades, mesmo sendo parte da linguagem, não se confunde com ela. A língua é considerada como "norma de todas as outras manifestações da linguagem" (SAUSSURE, 1975, p. 16-17). Há outras contribuições desse autor para a linguística, que marcaram as reflexões positivistas de sua época: a tese da arbitrariedade do signo, aceitando o convencionalismo e rejeitando o naturalismo, e a da língua como um sistema de valores, que vincula a Linguística ao princípio semiológico.

Ser caracterizada como fato social, presente nos membros de uma comunidade linguística, constituiu não só a base do estudo imanente da língua, mas também o paradigma que sustenta a Linguística da língua proposta por Saussure. A visão estrutural manteve-se até os anos 1970 e serviu de base para muitas outras pesquisas em diferentes áreas. No entanto, a partir dessa década, passou a ser foco das principais críticas, período em que várias abordagens foram se constituindo. Por exemplo, a Sociolinguística, a Linguística Textual, a Análise do Discurso, a Análise da Conversação e os estudos bakhtinianos foram traduzidos. (SANTOS; ALMEIDA, 2011b; 2012). 
Bakhtin/Volochínov (1981, p. 124) defenderam que "a língua vive e evolui historicamente na comunicação verbal concreta, não no sistema linguístico abstrato das formas da língua nem no psiquismo individual dos falantes". Fatores históricos, sociais, situações e condições em que ocorrem a fala são incluídos nessa teoria sobre o funcionamento da linguagem. Os autores elaboram o primado do dialogismo na linguagem, que passa a ser vista como sócioideológica, cuja unidade fundamental é o diálogo. Dessa perspectiva, ninguém fala sozinho; quando falamos ou escrevemos é para alguém, em alguma circunstância social, assim, é que a palavra serve de ponte entre o locutor e o interlocutor no ato interativo.

A posição desses autores contra as tendências filosófico-linguísticas coloca em evidência, também, o comportamento dos interlocutores na interação. Na visão dialógica, o locutor constrói seu enunciado em função do interlocutor, que tem um papel ativo, constitutivo na formulação dos enunciados. Visivelmente, é o outro (interlocutor) quem condiciona o que o locutor diz e, desse modo, ambos são colocados no mesmo plano. Dessa forma, Bakhtin/Volochínov (1981) e Bakhtin (2010a) criticaram os estudos centrados na oração e propuseram uma nova disciplina, cujo objeto de estudo seria as relações dialógicas. Inserir o locutor e o receptor no funcionamento da linguagem é admitir que o processo de compreensão não se limita à identificação de forma linguística.

$\mathrm{Na}$ perspectiva dialógica de Bakhtin e o Círculo, o modo de compreender ou de produzir sentido exige discussão acerca da unicidade da forma linguística e da polissemia, que é inerente às línguas, o que significa dizer que a significação não se prende a uma forma tomada de modo isolado ou fora das determinações sociais. A unicidade coloca o objeto como único e idêntico a si mesmo, enquanto a polissemia permite visualizar os vários sentidos de uma palavra. Conforme Bakhtin/Volochínov (1981, p. 106), "o sentido da palavra é totalmente determinado por seu contexto que não é fixo" nem é uma situação isolada, mas algo a se precisar.

Nessa abordagem, toda enunciação só pode ser concebida como produto da interação de dois indivíduos socialmente organizados, sendo a ela que devemos as mudanças semânticas. Bakhtin/Volochínov (1981, p. 131-132) asseguram que "compreender a enunciação de outrem significa orientar-se em relação a ela, encontrar o seu lugar adequado no contexto correspondente." A compreensão é sempre uma reação ao que o outro disse e provoca uma resposta. No processo de compreender, "locutor e receptor" (os interlocutores) introduzem o objeto a ser compreendido no contexto potencial da resposta. Todos esses valores se juntam no momento da produção do sentido que se realiza no processo de compreensão ativa e responsiva, forma de diálogo que leva à formulação de uma contrapalavra. A concepção de compreensão responsiva é fundamental para entendermos $\mathrm{O}$ funcionamento da linguagem. (SANTOS; ALMEIDA, 2011a,b, 2012, 2013).

A ciência vista por esse prisma, não se limita a pergunta e resposta, porque toda resposta gera uma nova pergunta, um novo diálogo é estabelecido; caso contrário, entra-se no conhecimento sistêmico, não atinge o princípio da distância, das complexas relações entre os sujeitos interpretados e o sujeito interpretador em que a precisão das Ciências Humanas é sempre a superação da alteridade do alheio sem sua transformação do puramento eu.

\section{AS POSSÍVEIS RELAÇÕES ENTRE ARQUIVOLOGIA E LINGUÍSTICA: CONSIDERAÇÕES FINAIS}

Os estudos da linguagem e do discurso são, em nosso entendimento, fundamentais para que se avancem os estudos de análise documentária, de uso e usuários, de paleografia, ontologia da informação, entre outras relações que podem ser estabelecidas. Não tivemos aqui a intenção de apontar resultados práticos, mas de se fazer reflexões teóricas como alicerce dos estudos e princípios dialógicos da linguagem necessários para a compreensão da relação interdisciplinar da Linguística com a Arquivologia.

Nessa perspectiva discursiva, apenas para exemplificar, estudos que podem contribuir para a análise documentária vão de encontro à proposta estruturalista que permite estudos distribucionais para elaboração de 
instrumentos dos vocabulários controlados, tesauros e sistemas de classificação. Não negamos aqui a importância desses estudos, mas pretendemos avançar nas discussões observando o esforço para a análise do documento que parte do contexto da enunciação para o próprio texto, os discursos que circulam na rede de vozes e formam o enunciado. Uma tentativa de refletir sobre os sentidos dos discursos e o aprimoramento de sistemas de indexação que devem considerar não apenas o texto, mas também o contexto sócio-histórico.

Nesse sentido, não há como deixar de valorizar a ideologia que perpassa todos os textos e a não-neutralidade que os discursos são elaborados. Se a linguagem pode ser um meio de dominação, a linguagem documentária não pode ser instrumento escamoteador da realidade quando o analistalarquivista ler e representa a informação documentária. Essa visão que vincula os enunciados às esferas de atividade humana evidencia não só o dialogismo da linguagem, como explica a multiplicidade de gêneros e, consequentemente, de sentidos que um texto apresenta.

Neste curto espaço que temos aqui, vamos fazer uma breve exemplicação do diálogo entre as áreas a respeito da ideologia e da nãoneutralidade pelo menos em um aspecto: tipologia documental. Quanto à tipologia documental, comecemos a entender que as categorias de classificação dos documentos arquivísticos ocorrem quanto: à entidade arquivística, ao gênero, à espécie, à natureza, aos valores dos arquivos; ao suporte da informação.

Primeiramente, o primeiro passo a se observar é quem produz ou acumula os documentos. Sendo os documentos arquivísticos públicos ou privados produzidos e acumulados, de forma natural, ao longo de suas vidas, por uma entidade (instituição ou organização administrativa), são resultantes de ações de sujeitos que exercem a função de fazer a gestão dos documentos e, posteriormente, preservá-los para garantir acesso às informações ao usuário que, assim, o solicite.

Em segundo lugar, identificar os gêneros dos arquivos (documentos textuais, iconográficos, sonoros, filmográficos, audiovisuais, informativos, cartográficos, micrográficos) e observar que podem ocorrer, simultaneamente em alguns documentos, características peculiares tanto a um gênero quanto a outro. No dizer da linguística, os gêneros materializado em texto não precisam conter uma forma fixa e exclusiva de ser constituído. A mesma lógica se encontra ao observarmos à espécie dos arquivos.

Bellotto (2006) classifica os documentos arquivísticos, quanto à especie, em seis blocos para os atos administrativos: normativos, enunciativos, de assentamento, comprobatórios, de ajuste, de correspondência; e esclarece a diferença entre espécie e tipo documental. A espécie é a configuração que assume um documento de acordo com a disposição e a natureza das informações nele contidas; e o tipo documental assume a espécie documental de acordo com a atividade que a gerou, por exemplo: Contrato (espécie), Contrato de Venda (tipo).

Do mesmo modo, quanto à natureza dos arquivos em especial ou especializado, requer uma atenção especial por causa da forma física, por isso os documentos merecem um tratamento diferenciado ao registro, acondicionamento, controle e preservação; ou são especializados por terem sob custódia os documentos resultantes da experiência humana em um campo específico, como arquivo médico, jurídico, etc.

A esta análise não podem faltar o suporte da informação e os valores dos arquivos. $\mathrm{Na}$ acepção arquivística, suporte é a base em que a informação é registrada; os valores se referem à utilidade que os documentos tem ou podem vir a ter para uma instituição e são classificados em primário ou administrativo e secundário ou histórico. Certamente, todos os documentos terão um valor primário, mas nem todos poderão ter um valor secundário, um valor histórico relativo à idade permanente.

Destarte, o que esta pequena exposição sobre tipologia documental tem a ver com as concepções de linguagem, com os princípios dialógicos de linguagem? $\mathrm{O}$ objeto das ciências humanas é o "ser expressivo e falante", ou seja, o objeto da pesquisa é objeto falado, é o próprio texto fazendo um duplo movimento: como resposta ao já dito e também sob o condicionamento da resposta ainda não 
dita, mas solicitada e prevista, assim o objeto também é falante ao explicar e compreender.

As relações estabelecidas entre espécie e tipo, por exemplo, estão associadas às definições de gênero discursivo de Bakhtin que delibera como formas relativamente estáveis de enunciados; portanto, há uma forma arquitetônica do gênero e será ajustada a sua esfera de comunicação, por isso relativamente estável nas suas características: estrutura composicional, estilo e conteúdo temático.

$\mathrm{O}$ processo de produção de texto documental deve estar em sintonia com as condições e contexto de produção do documento: quem, onde, quando produziu? Com quais finalidades? Em qual suporte? Quanto à não-neutralidade, é uma visão que não corresponde à teoria bakhtiniana, porque a palavra assume um sentido em cada contexto, fato que mostra o caráter polissêmico e plurivalente que ela comporta pela natureza dialógica da linguagem. Para Bakhtin, são tantas as significações quantos forem os contextos, que não estão prontos, mas sempre em situação de interação.

Fica evidente a responsabilidade do interlocutor ao ler o texto (o arquivista), ao classificá-lo e/ou ao indexá-lo, pois não parece pertinente analisar o texto com um engessamento ou apenas com um olhar positivista e estruturalista, já que os sentidos são construídos pelas vozes que circulam no texto, pelo gênero discursivo que corresponde a uma esfera de comunicação.

Bakhtin define o texto como um tecido de muitas vozes que se entrecruzam, completamse e respondem umas às outras ou polemizam entre si no seu interior e o coloca no centro de suas investigações sobre o homem. O enunciado é um todo inseparável, um ato, em uma cadeia discursiva, o texto é um encadeamento discursivo. Essa visão que vincula os enunciados às esferas de atividade humana evidencia não só o dialogismo da linguagem, como explica a multiplicidade de gêneros e, consequentemente, de sentidos que um texto apresenta. (SANTOS, 2013).
Esta pequena exposição apresenta a importância do estudo de linguagem para a Arquivologia. Independente da perspectiva teórica para análise documentária, tipologia ou outra temática da área, o que propomos refletir são os aspectos que estão relacionados à produção e recepção dos documentos, sua relação com interlocutores (produtores e usuários). Um campo, por exemplo, para investigação, nesta perspectiva, são os estudos de classificação que, segundo Schellenberg (2006), é um status gerencial, de uma organização relacionada aos documentos em fase ativa, cujos métodos de classificação baseiam-se na estrutura e nas funções do órgão, e os estudos sobre arranjo que é baseado na proveniência e na ordem original, para os arquivos inativos. Para este último, a organização de instrumentos de pesquisa em arquivos permanentes, tais como guia, catálogos, por exemplo, são espaços de investigação quanto ao gênero discursivo, suas características composicionais que dependem das práticas sociais e discursivas.

Mediante tantas proposições, para compreender o conceito de zonas fronteiriças entre a Arquivologia e a Linguística, é necessário que os profissionais envolvidos no processo de criação e implantação de matrizes curriculares baseadas na interdisciplinaridade e na resolução de problemas reflitam sobre a sua própria formação disciplinar e dialoguem sistemática e continuamente com os profissionais de outras áreas, com a intenção de produzir conhecimento teórico e empírico que possa orientar e alimentar as transformações requeridas nos currículos de cursos de graduação e, mais do que isso, seja um exemplo de atuação coletiva para os graduandos que estão inseridos nesse processo.

Por fim, acreditamos que o inacabamento do conhecimento se constrói na formulação de uma consciência crítica e autocrítica do que se pretende mudar, cujo entendimento de ciência sempre será algo discutível para vir a ser objeto científico.

Recebido em: 01/12/2016

Aceito em definitivo em: 31/05/2017 


\section{THE INTERDISCIPLINARITY BETWEEN ARCHIVAL SCIENCE AND LANGUAGE: SCIENCE IN THE LIGHT OF THE DIALOGICAL PERSPECTIVE OF SPEECH}

\section{Abstract}

The Archival, as a science, is a contemporary phenomenon and it configures with perspective apart from the urgency of archives management, as a science discipline in permanent construction, it has autonomy and interdisciplinary in relations with other sciences. Therefore, the objective of this article is thinks over the science conception according to baktin's study for the Archival Science, assuming a position of cooperation between the interdisciplinary departments. The bases of Bakhtin's Circle thought are constructed from the critique of two philosophical tendencies: the classic stylistic that is based in idealism and the structuralism situated in studies of unspecific system. The object is to be significant and speaker, and the conception about language can be understood by a process of social interaction that is based in discussion with the other (it is associated with the idea of social subject, historic and ideologically situated, that is formed in interaction with the other) and in the unity of differences.

Keywords: Science. Language. Archival Science. Interdisciplinary. Dialogue.

\section{REFERÊNCIAS}

AMORIM, M. O pesquisador e seu outro: Bakhtin nas Ciências Humanas. São Paulo: Musa, 2004.

AMORIM, M. Cronotopia e exotopia. In: BRAIT, B. (Org.). Bakhtin: conceitos-chave. São Paulo: Contexto, 2006. p. 95-114.

BAKHTIN, M. Metodologia das ciências humanas. In: BAKHTIN, M. Estética da criação verbal. 5. ed. Tradução de: Bezerra, P. São Paulo: Martins Fontes, 2010a. p. 393410.

. Os gêneros do discurso. In:

BAKHTIN, M. Estética da criação verbal. 5. ed. Tradução de: BEZERRA, P. São Paulo: Martins Fontes, 2010b. p. 261-306.

BAKHTIN, M.; VOLOCHÍNOV, V. N. Marxismo e filosofia da linguagem: problemas fundamentais do método sociológico na ciência da linguagem. 2 ed. Tradução de: Lahud, M.; Vieira, Y. F.; Wisnik, L. T.; Cruz, C. H. D. C. São Paulo: Hucitec, 1981.
BellotTo, H. L. Arquivos Permanentes: tratamento documental. 4. Ed. Rio de Janeiro: Editora FGV, 2006.

FARACO, C. A. Linguagem \& Dialógica: as ideias linguísticas do círculo de Bakhtin. São Paulo: Parábola, 2009.

JARDIM, J. M. A pesquisa em Arquivologia: um cenário em construção. In: VALENTIM, M. L. P. (Org.). Estudos avançados em Arquivologia. São Paulo: Cultura Acadêmica, 2012. p. 135-154.

SANTOS, E. C.; ALMEIDA, M. F. Linguagem como interação: reflexões no contexto da arquivologia. In: A linguagem e a informação documentária: intermediações e ressignificações possíveis. Recife: Bagaço, 2011 .

A palavra de outrem: as fronteiras do fenômeno social da interação verbal. In: ALMEIDA, M. F. (Org.).

Bakhtin/Volochínov e a filosofia da linguagem: ressignificações. Recife: Bagaço, 2011b.

Diretrizes bakhtinianas para o método sociológico em ciências humanas. Macabéa: 
Revista Eletrônica do NETLLI, Cidade da revista, v. 1, n. 2, p. 77-92, dez. 2012.

. Os diários dialogados: as vozes dos estudantes sobre a prática pedagógica.

Cadernos do IL, Porto Alegre, v. 1, n. 46, p. 45-63, jun. 2013.

SANTOS, E. C. Uma proposta dialógica de ensino de gêneros acadêmicos: nas fronteiras do Projeto SESA. 2013. 418p. Tese (Doutorado em Linguística) - Programa de Pós-graduação em Línguística - PROLING, Universidade Federal da Paraíba, João Pessoa, 2013.

SAUSSURE, F. de. Curso de Linguística Geral. São Paulo: Cultrix, 1975.
SCHELLENBERG, T. R. Arquivos

Modernos: princípios e técnicas. 6. Ed. Rio de Janeiro: Editora FGV, 2006.

\section{SCHMIDT, C. M. S. Arquivologia e a construção do seu objeto científico: concepções, trajetórias, contextualizações. 2012. 320p. Tese (Doutorado em Ciência da Informação) -Escola de Comunicação e Arte, Universidade de São Paulo, São Paulo, 2012. \\ SOBRAL, A. Ética e estético: na vida, na arte e na pesquisa em Ciências Humanas. In: \\ BRAIT, B. (Org.). Bakhtin: conceitos-chave. 2. ed. São Paulo: Contexto, 2005. p. 103-122.}

\section{AGRADECIMENTOS}

Agradecemos ao programa de incentivo à pesquisa da PRPGP da UEPB - PROPESQ pelo apoio dado ao projeto Linguagem, cultura e memória: investigando as fronteiras do projeto SESA.

\footnotetext{
${ }^{1}$ Para um aprofundamento a respeito dessas vertentes, ver a tese de doutorado de Schmidt (2012) que apresenta trajetória, concepções e contextualizações da construção do objeto científico em Arquivologia.
}

\footnotetext{
2 De acordo com a CAPES, a classificação original das Áreas do Conhecimento apresentou uma hierarquização em quatro níveis, que vão do mais geral aos mais específicos, abrangendo 08 grandes áreas, 76 áreas e 340 subáreas do conhecimento. Sendo assim, a Arquivologia estaria em uma subárea da Ciência da Informação na avaliação de uma grande área das Ciências Sociais Aplicadas, a Educação pertence à grande área das Ciências Humanas e a Linguística diz respeito à grande área Linguística, Letras e Artes; em nosso entendimento, todas essas são Humanas e Sociais e sempre que nos referirmos às Ciências Humanas neste trabalho, estamos também situados nas Ciências Sociais Aplicadas.
} 